\title{
A Concise Route to (+)-Lactacystin
}

Hidenori Ooi, Norihisa Ishibashi, Yoshiharu Iwabuchi, Jun Ishihara, and Susumi Hatakeyama*

Graduate School of Biomedical Sciences, Nagasaki University, Nagasaki 852-8521, Japan

susumi@net.nagasaki-u.ac.jp

Supporting Information Available. ${ }^{1} \mathrm{H}$ NMR and ${ }^{13} \mathrm{C}$ NMR spectra of compounds 1-4, 9-11, 15, 17, 19-23. 


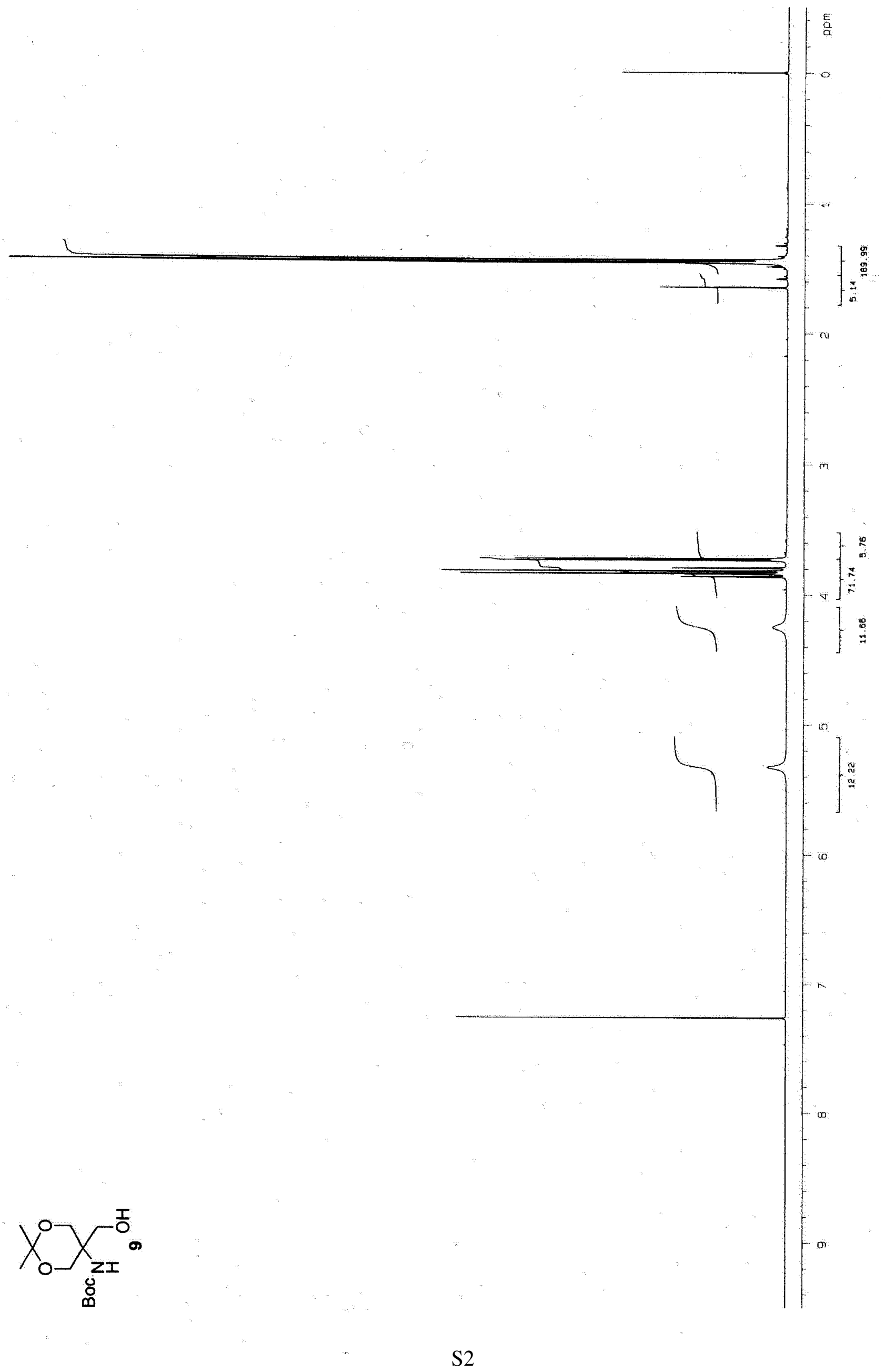




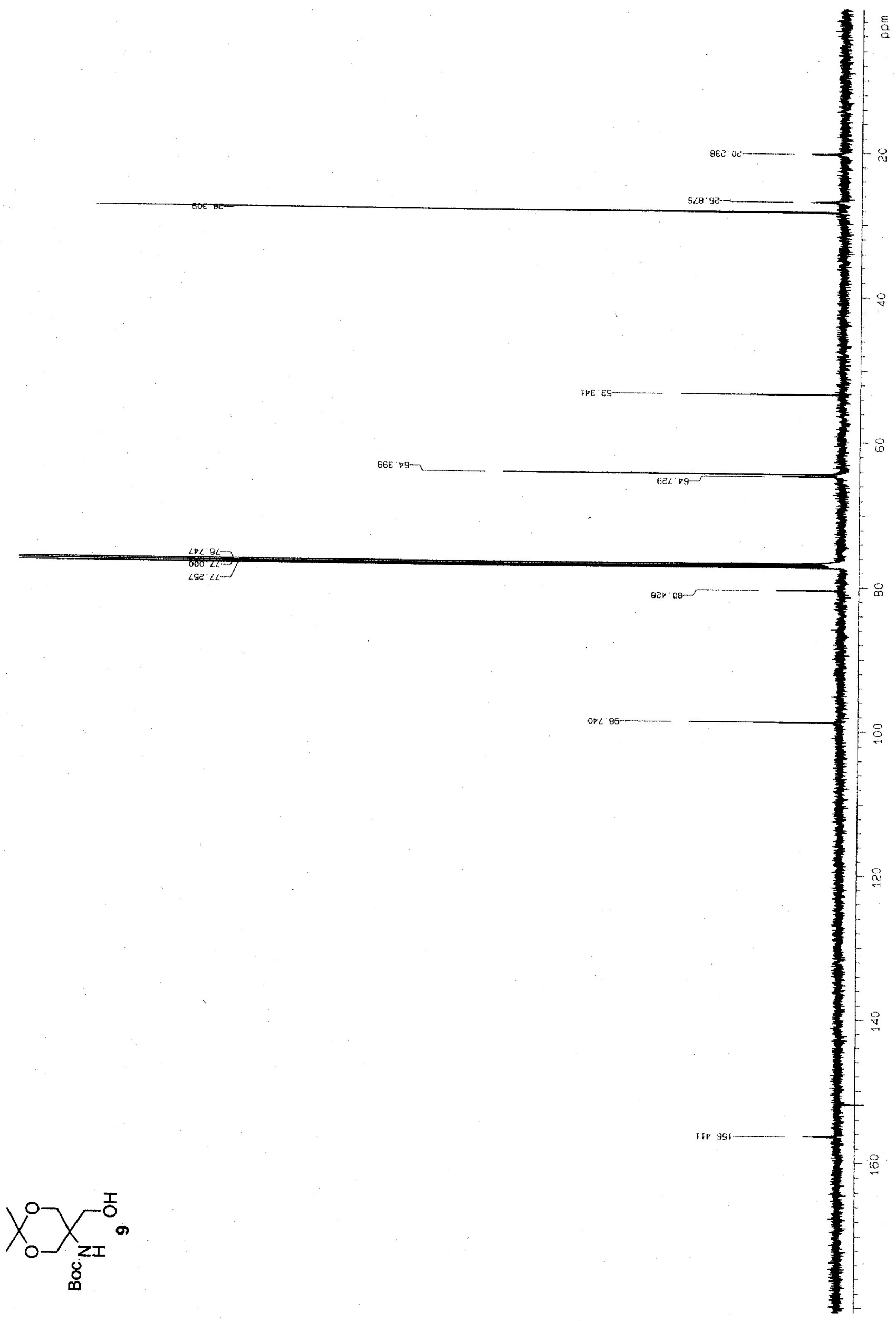




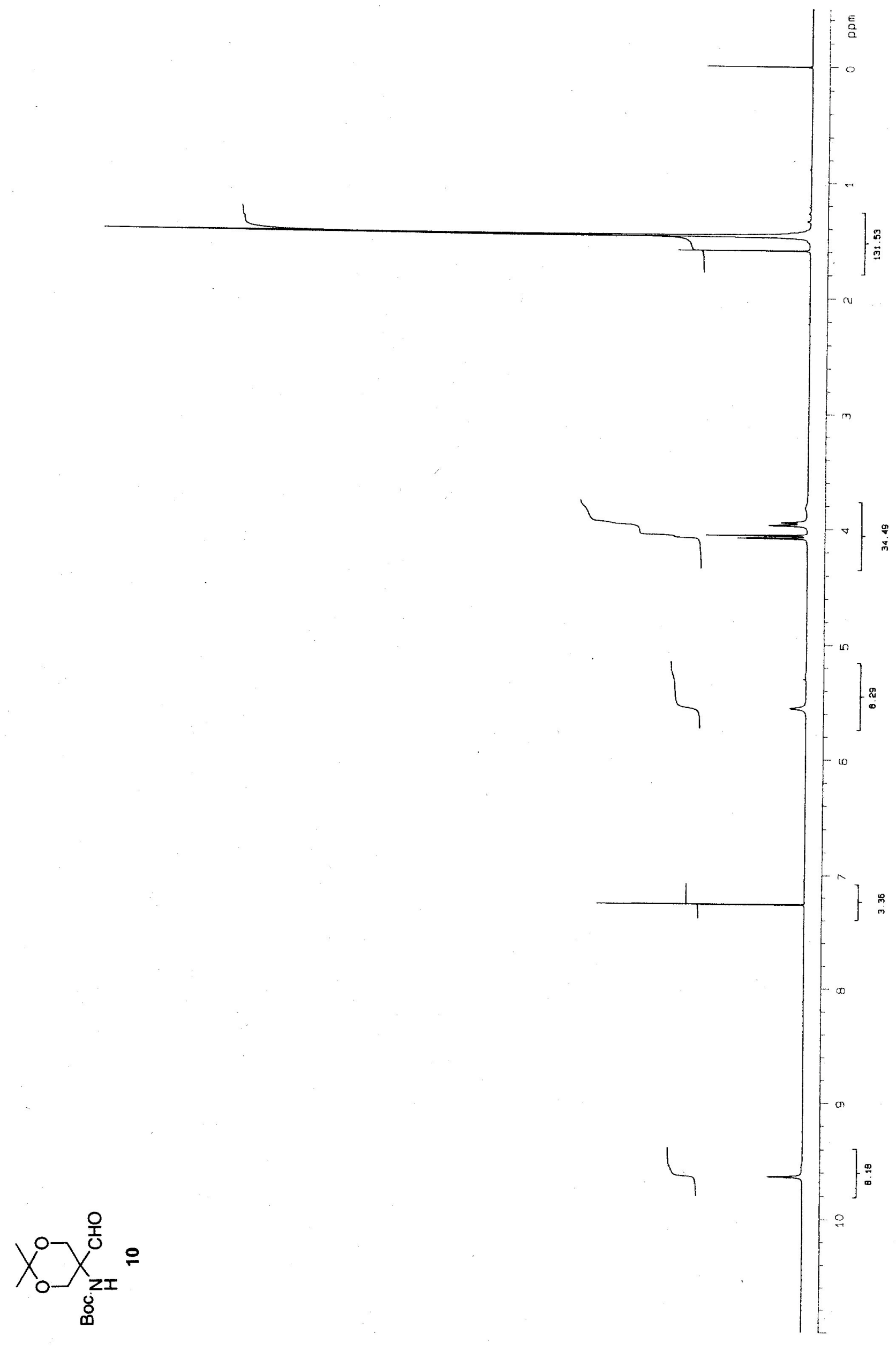




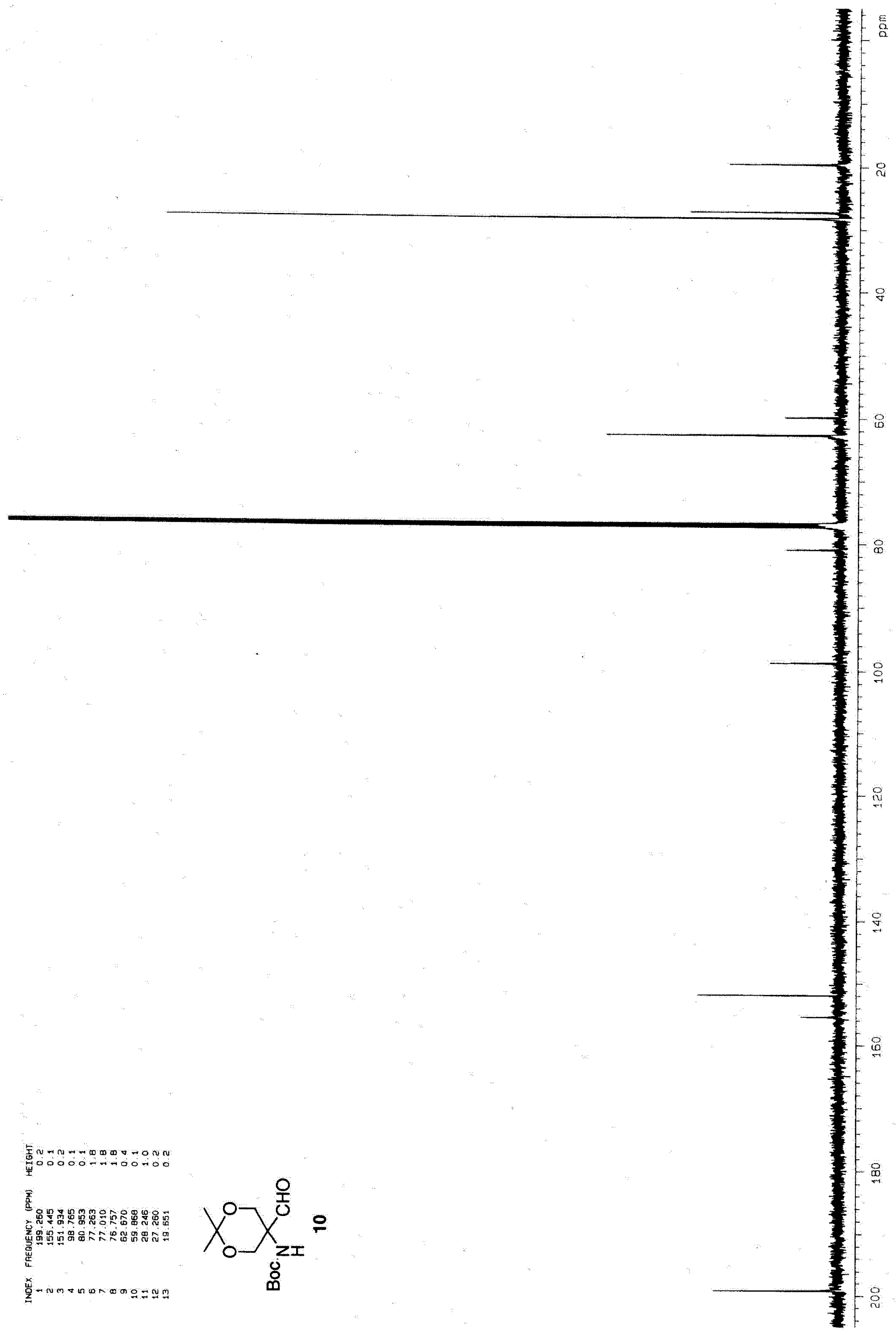




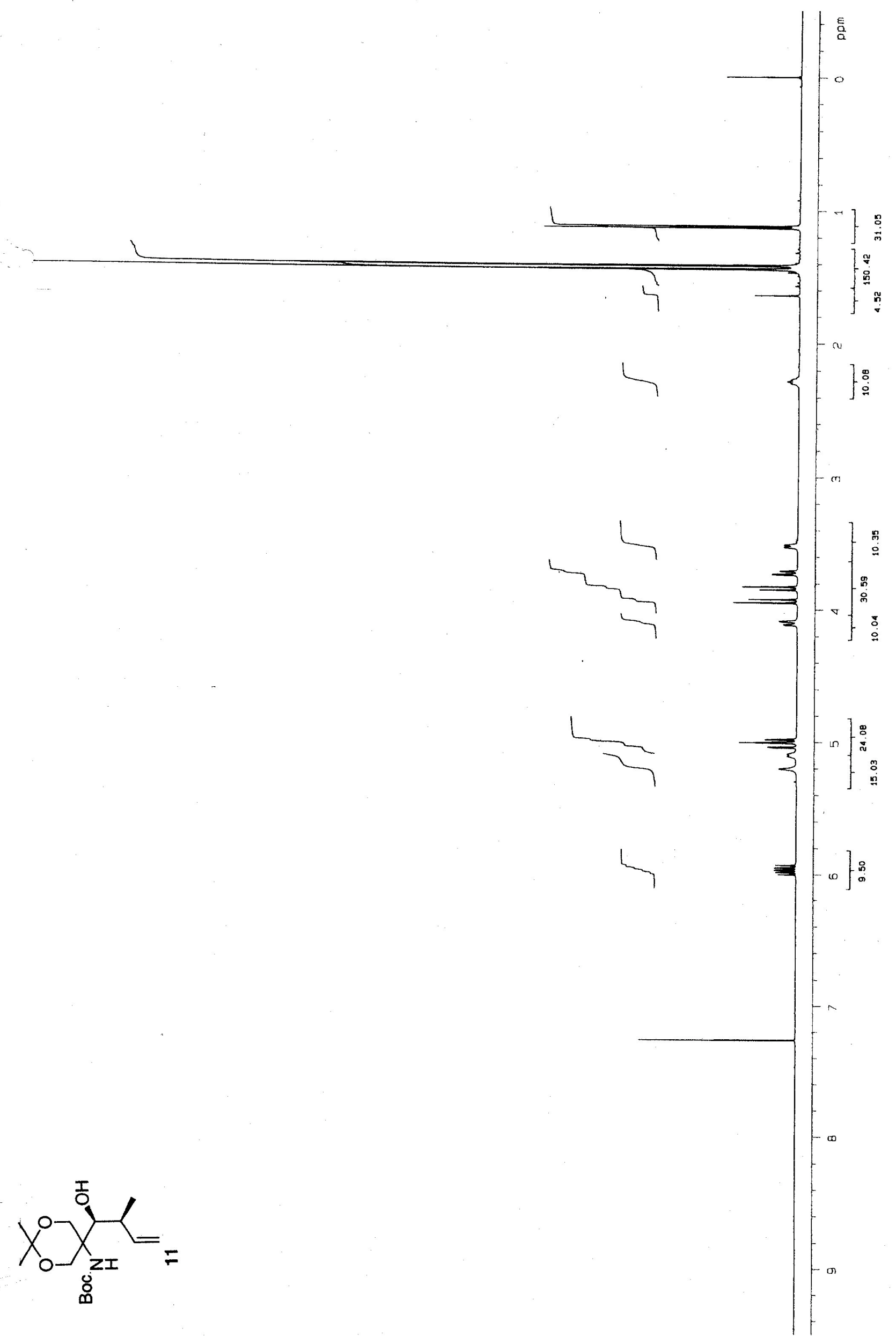




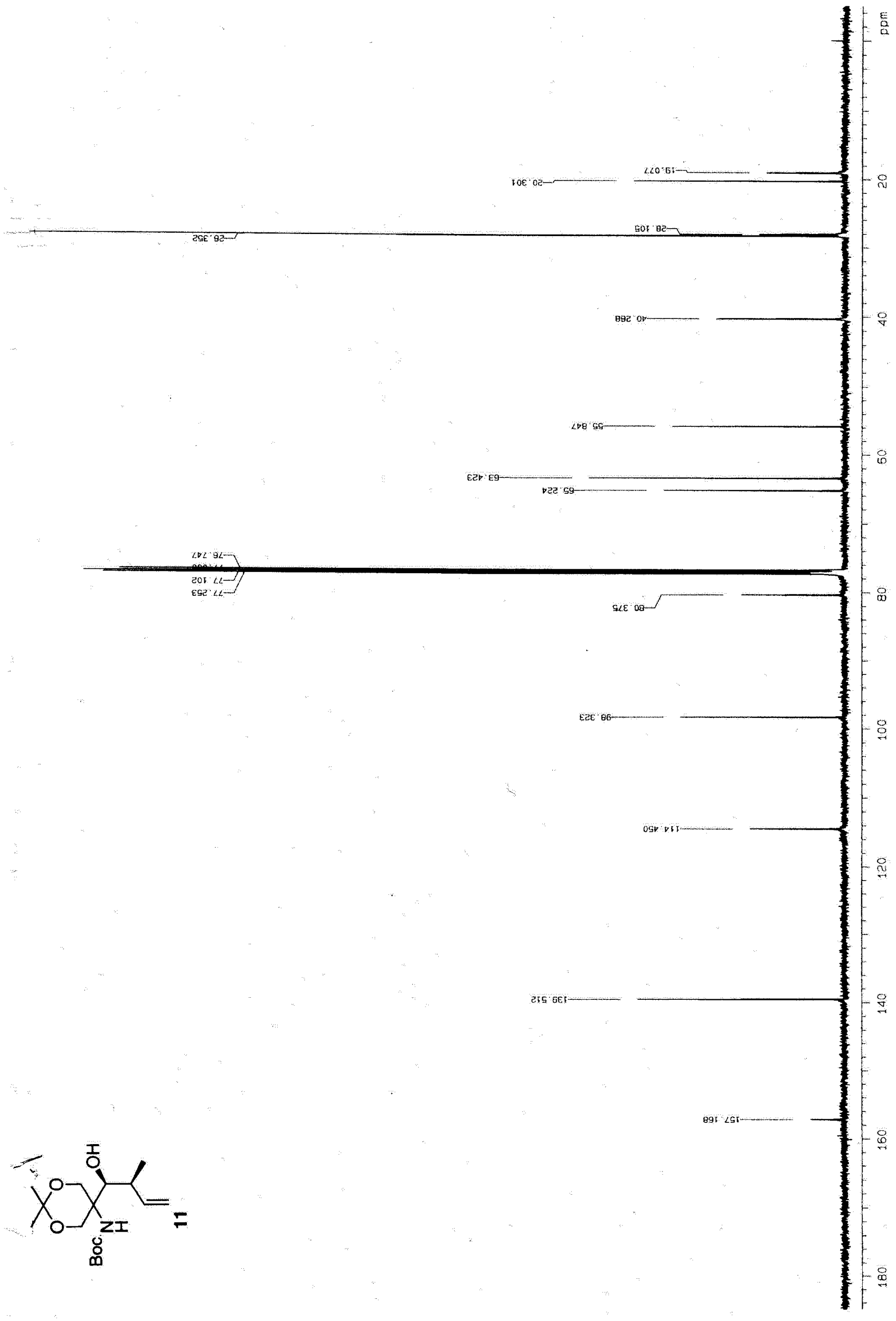




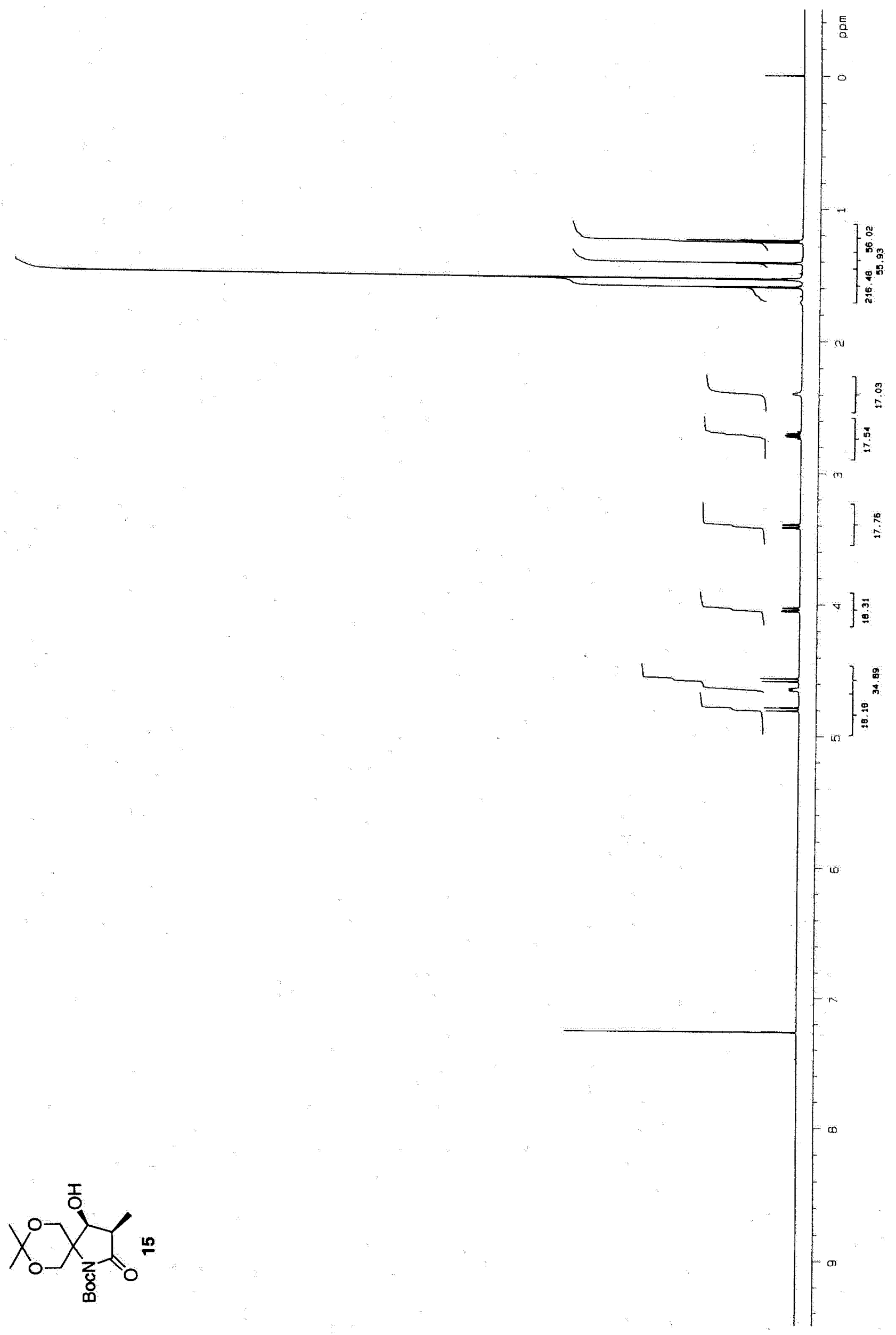




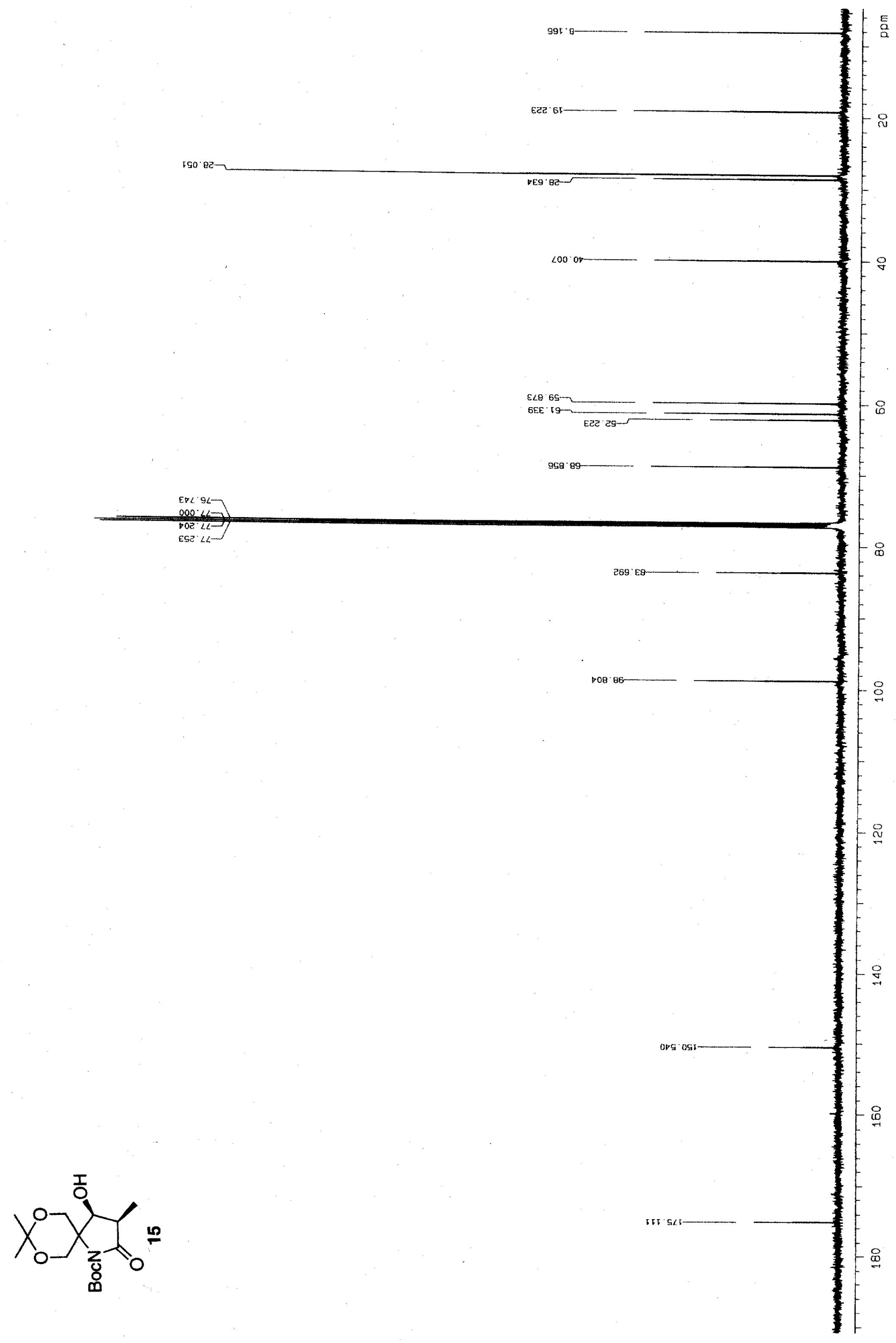




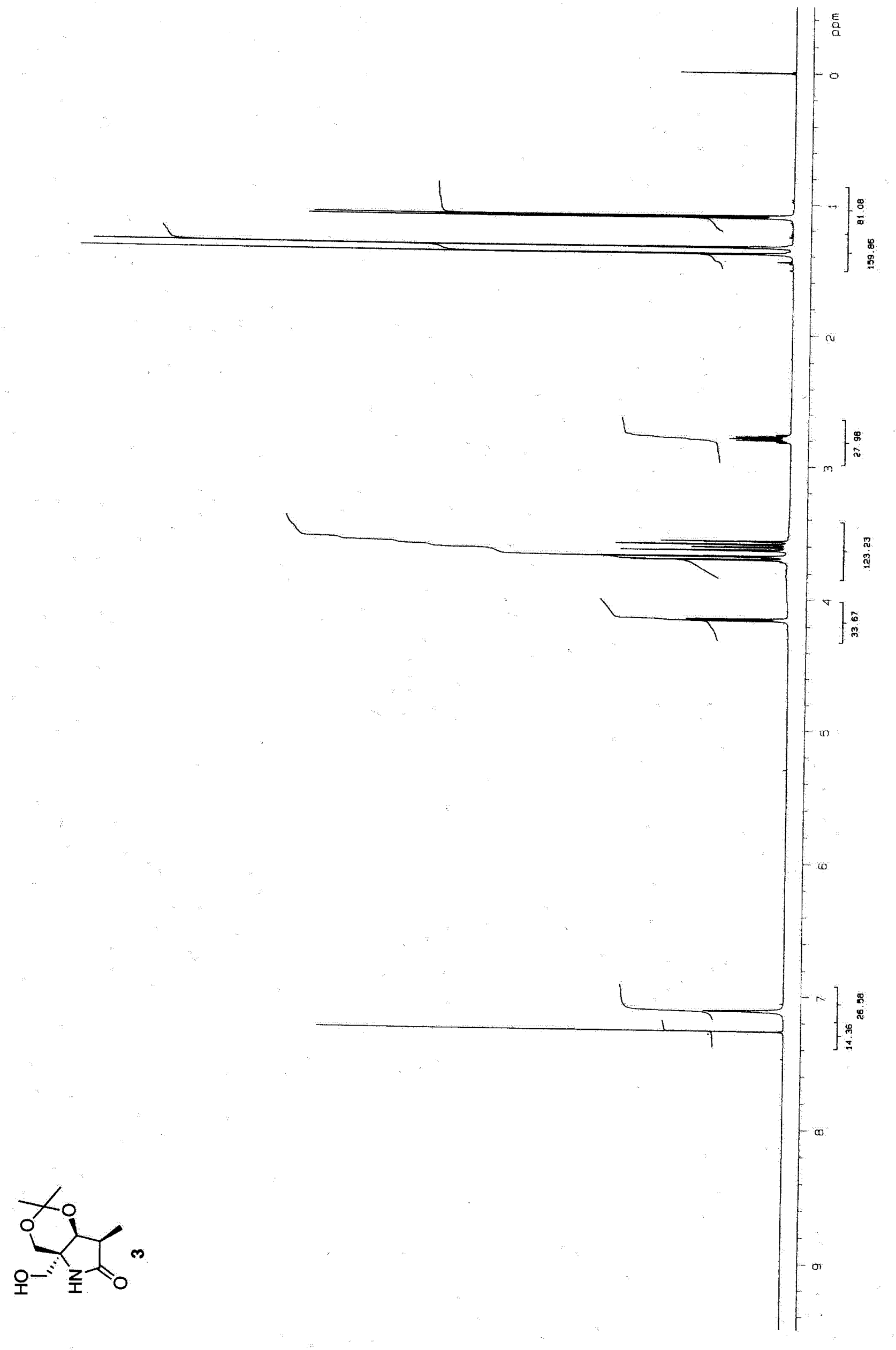




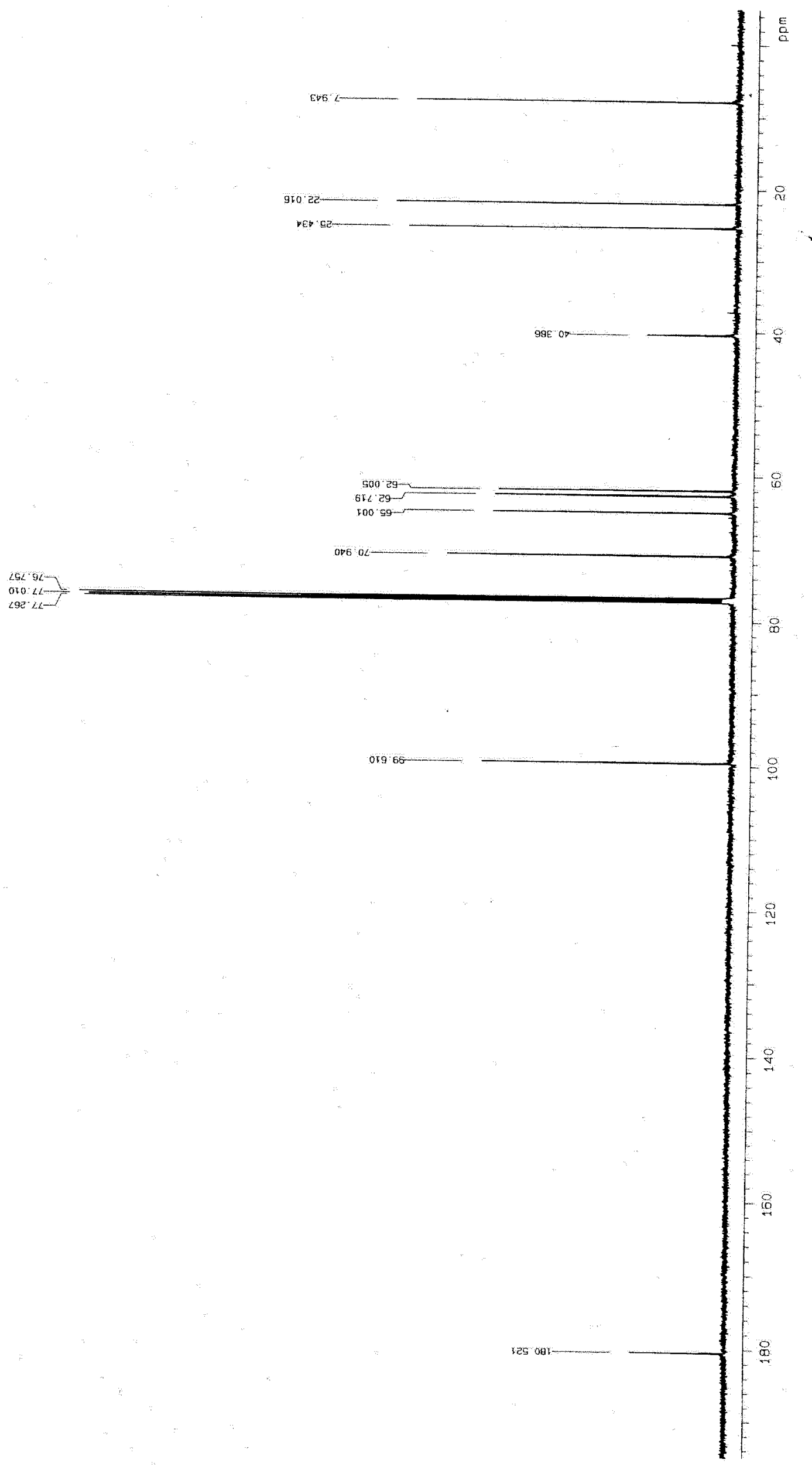




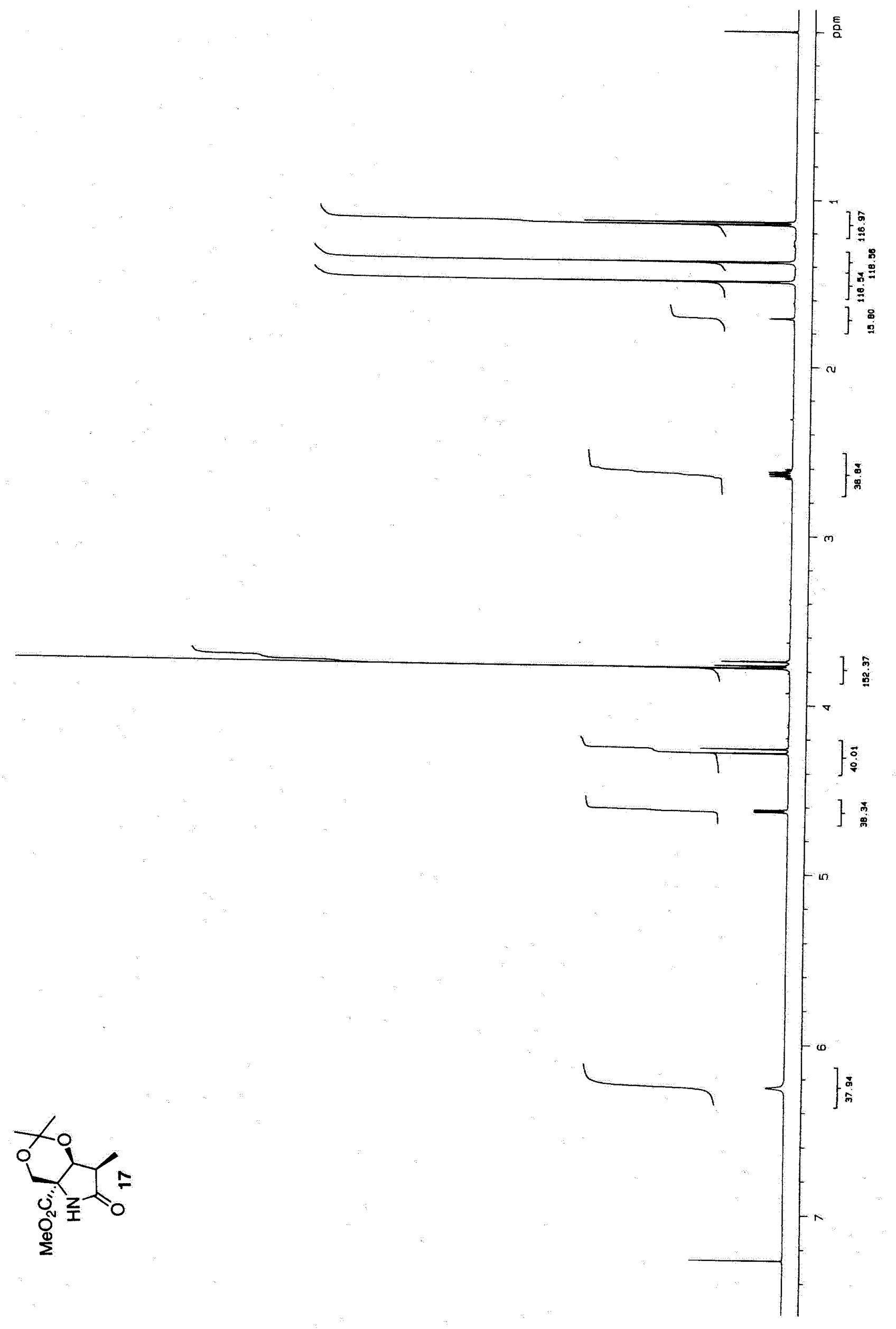




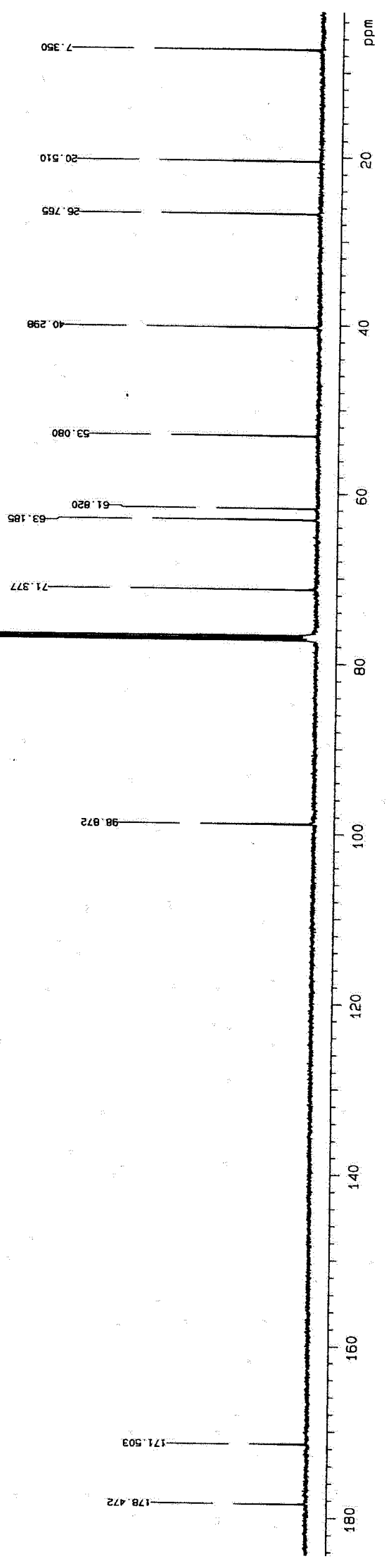




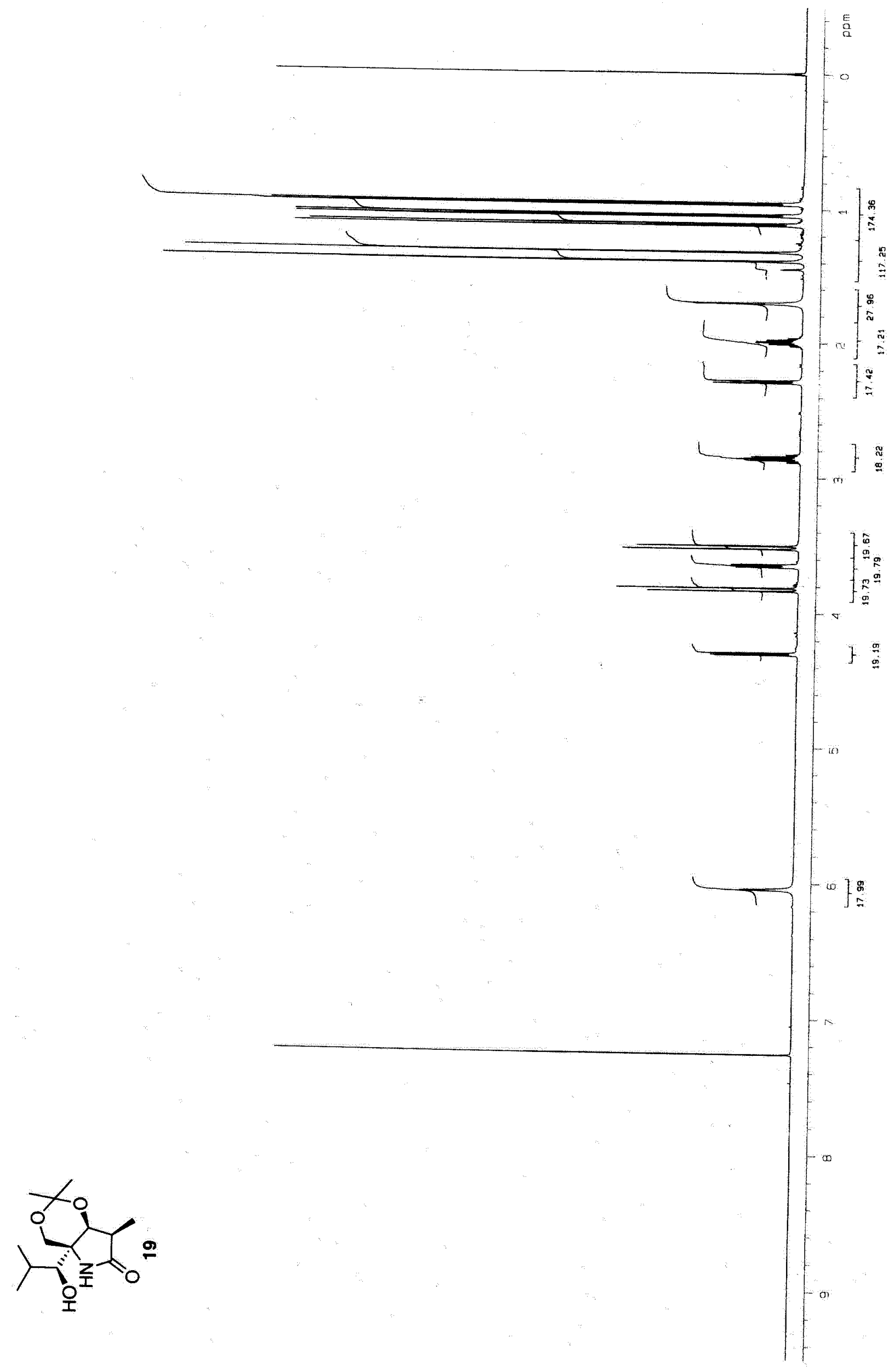



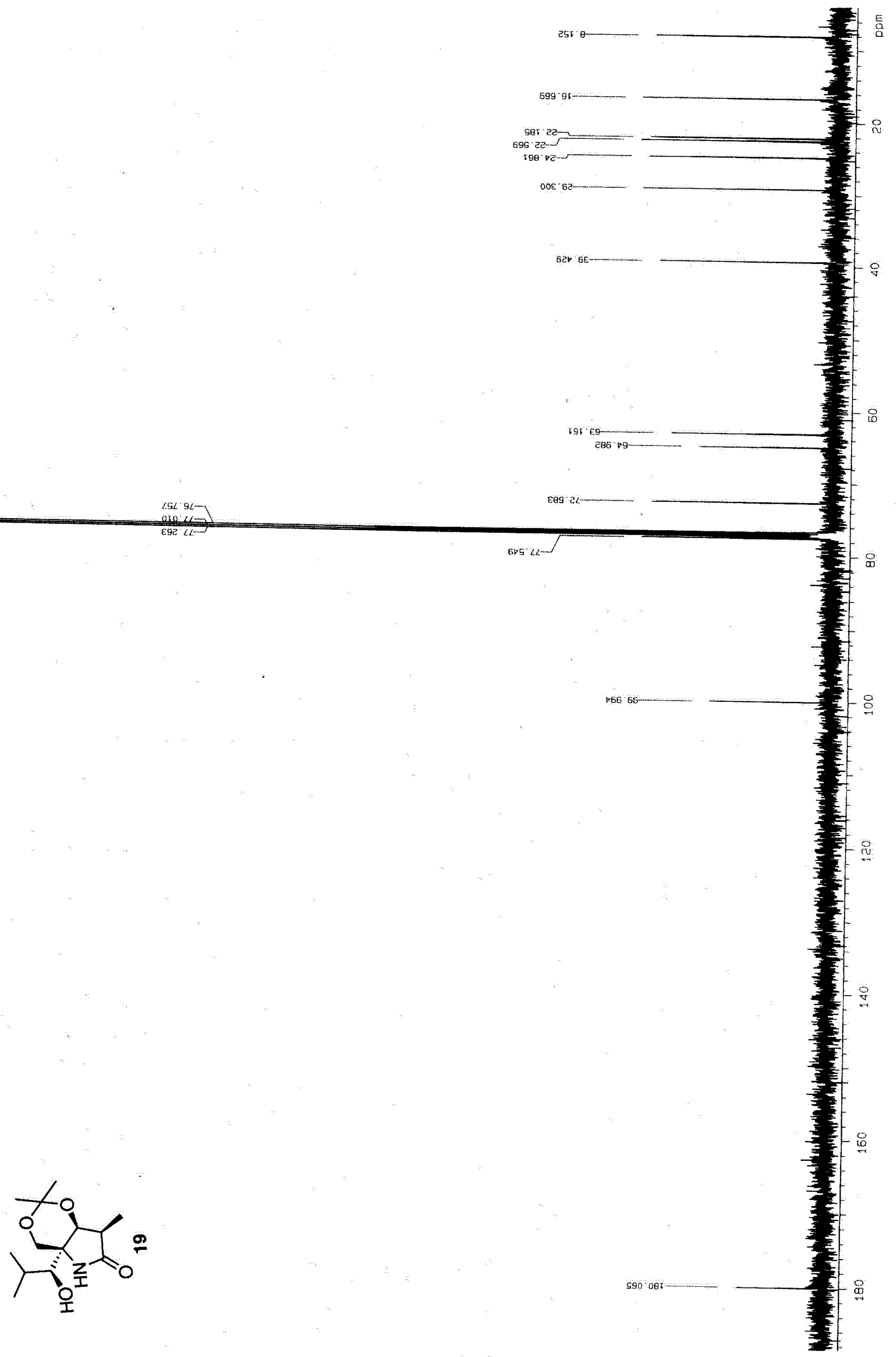


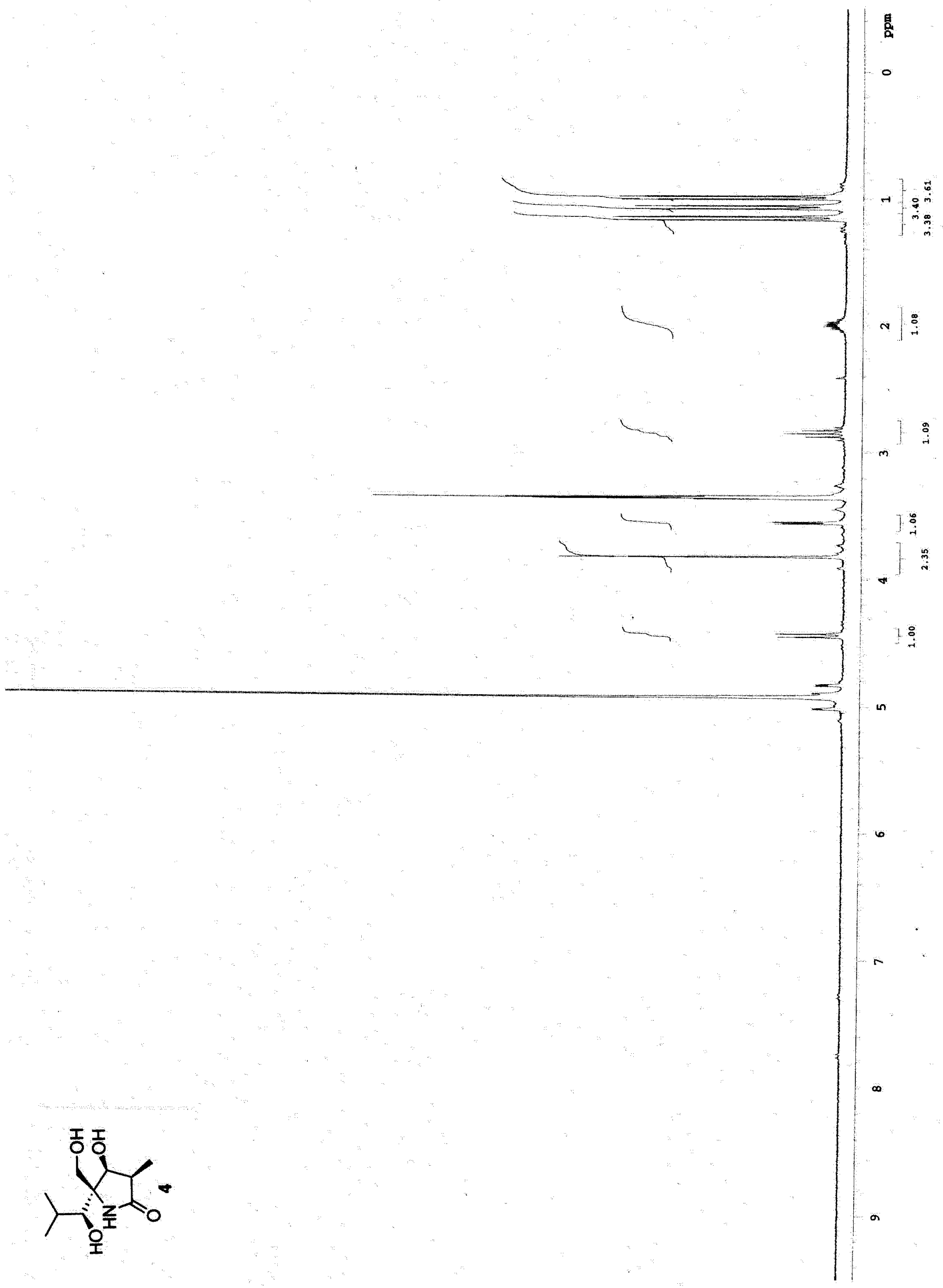




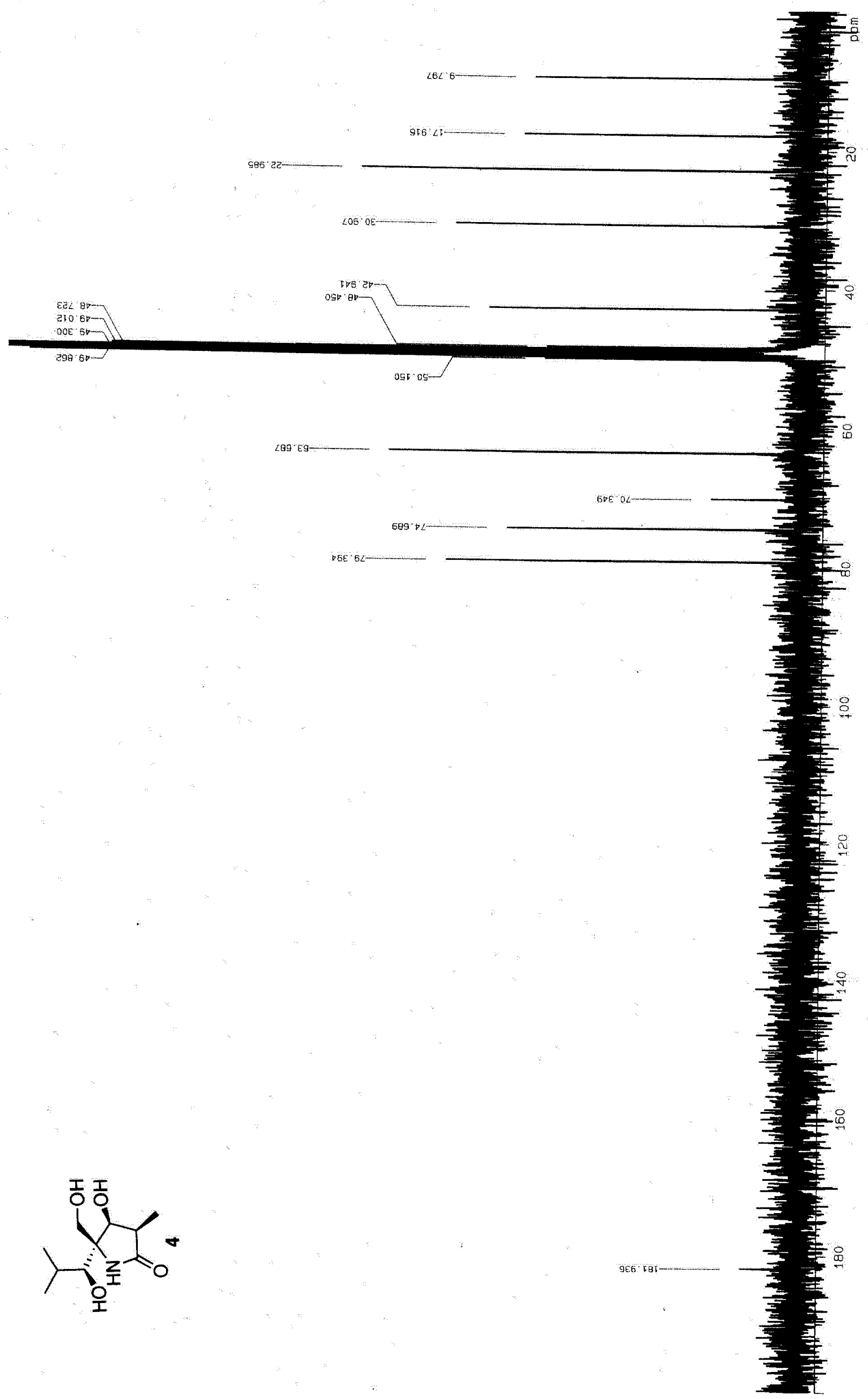




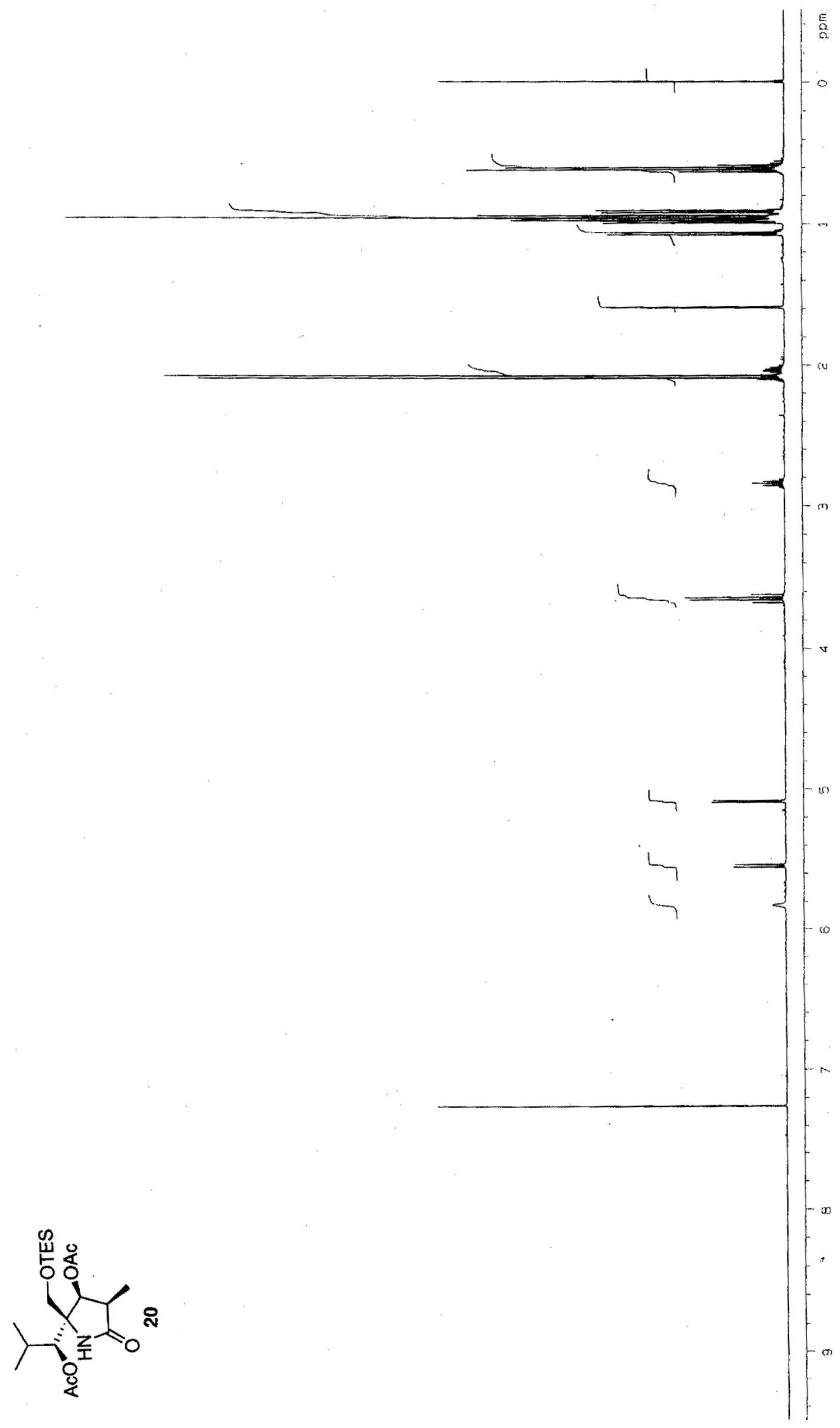




$$
1
$$




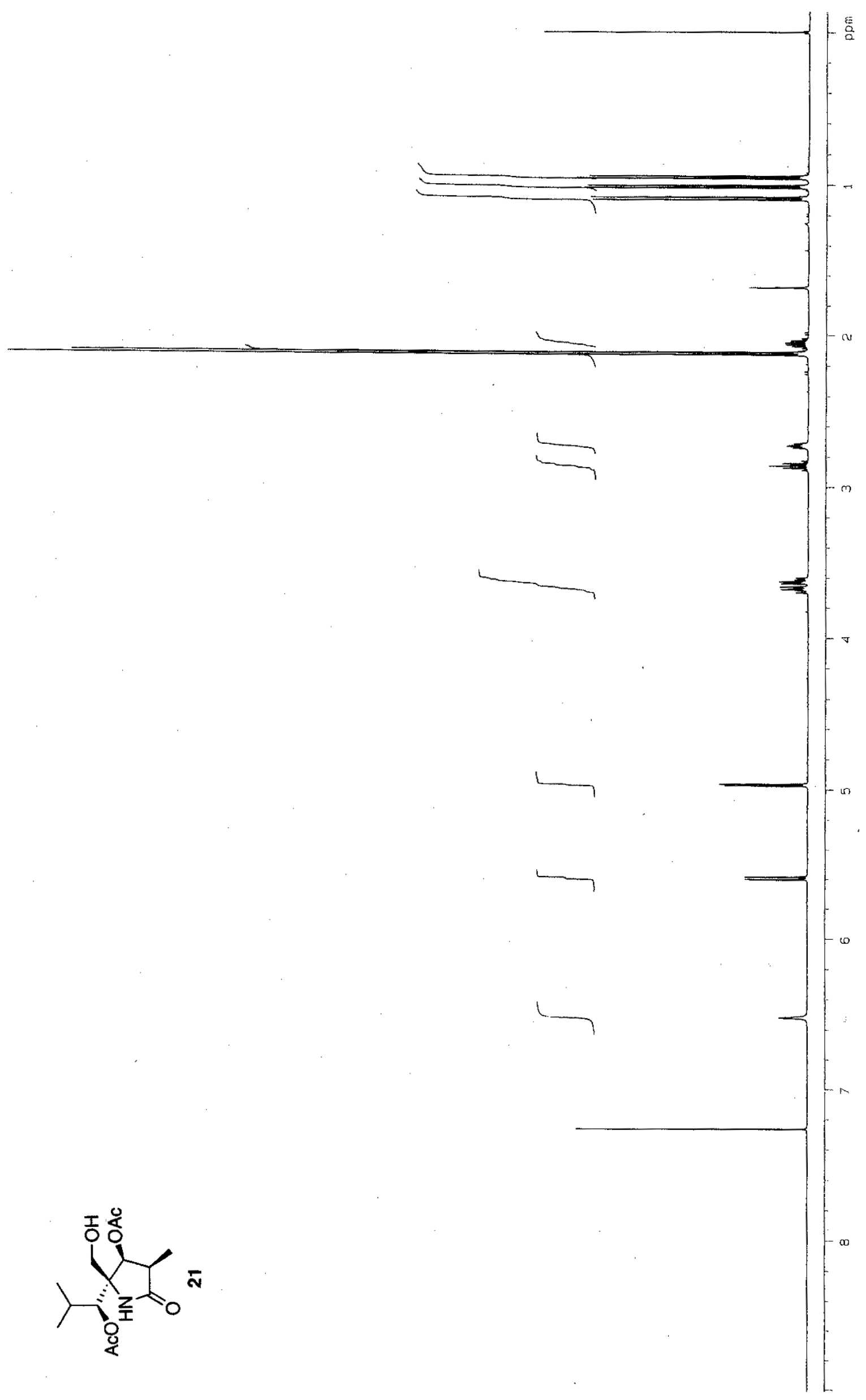




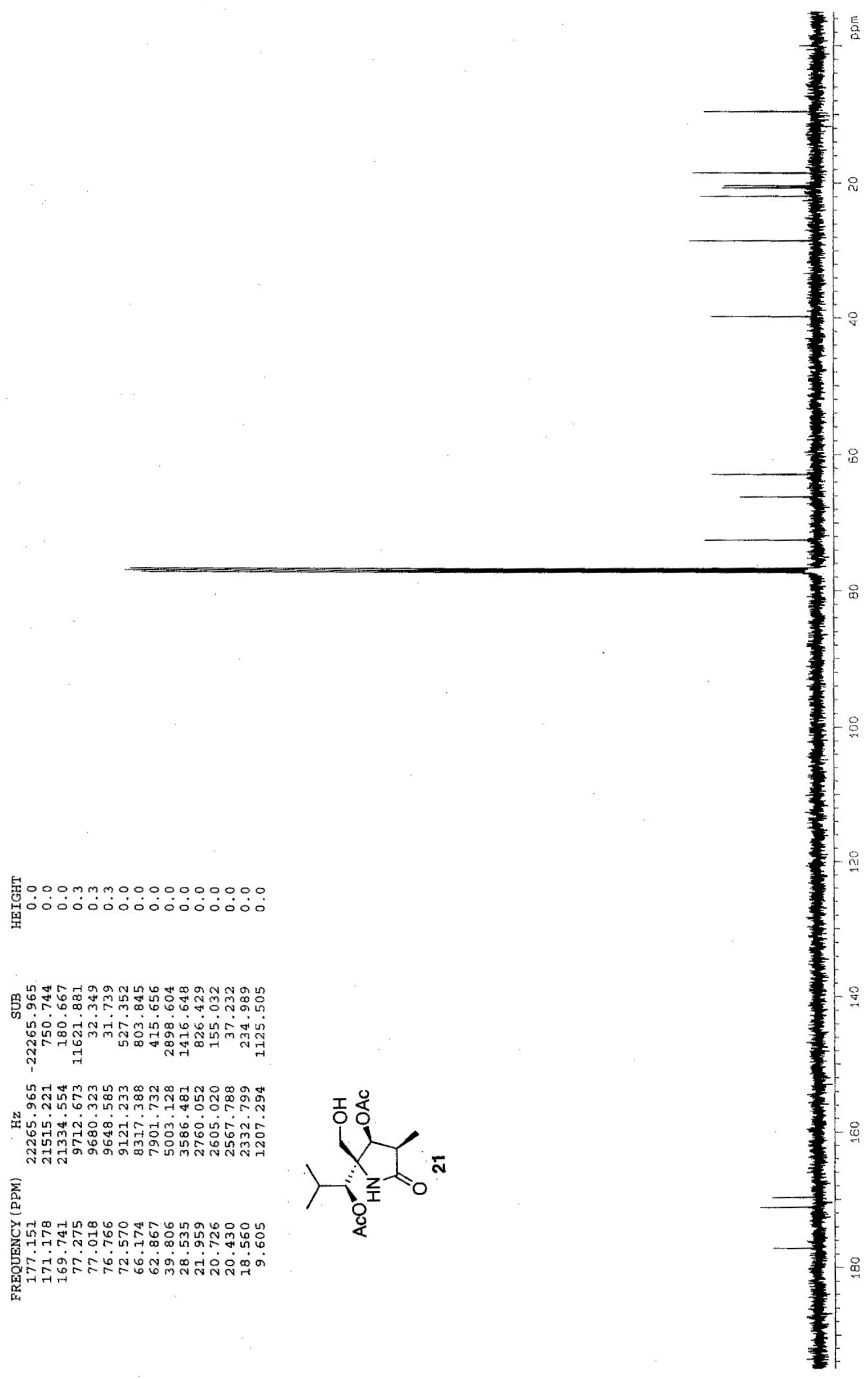




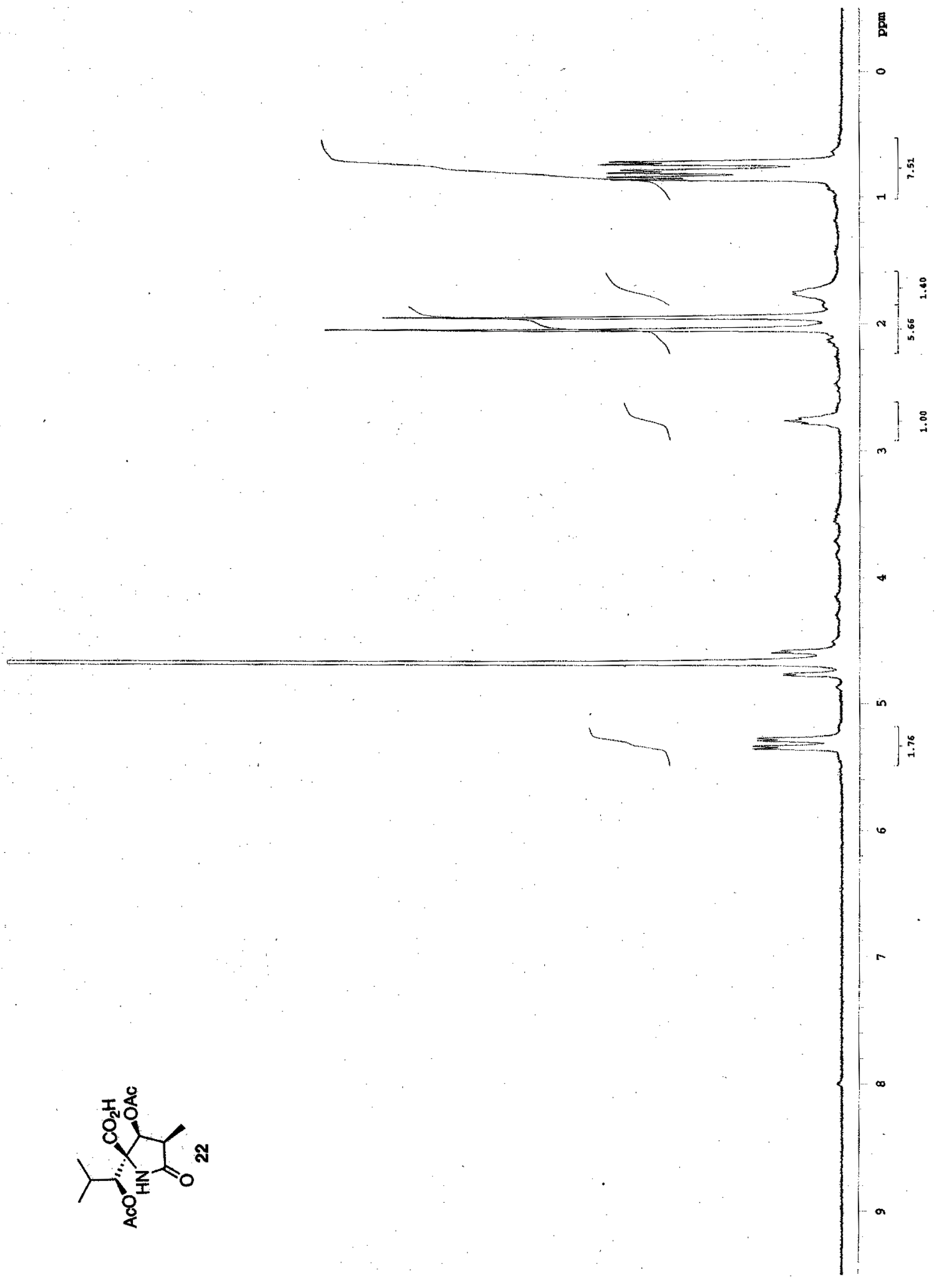




$$
1
$$




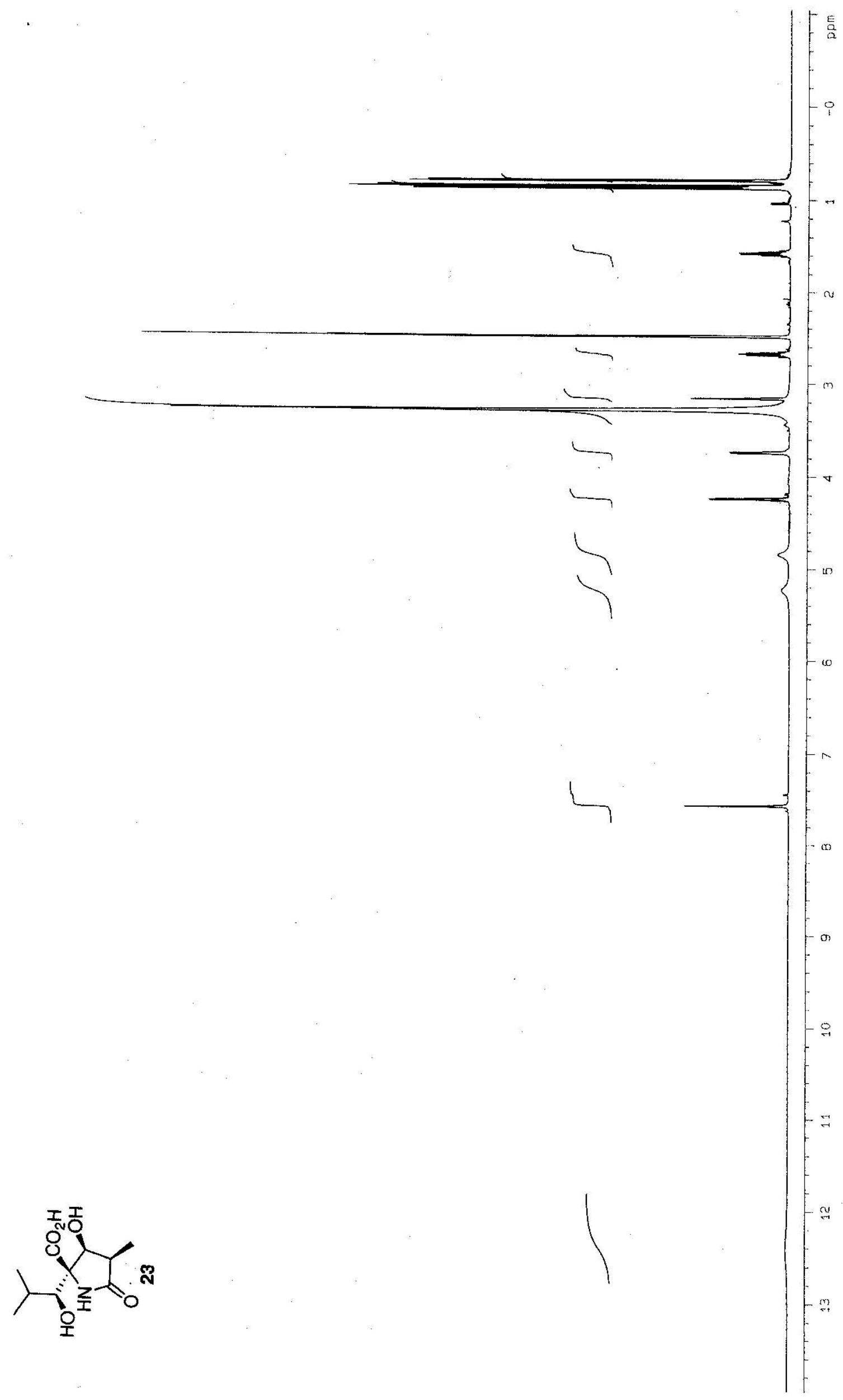




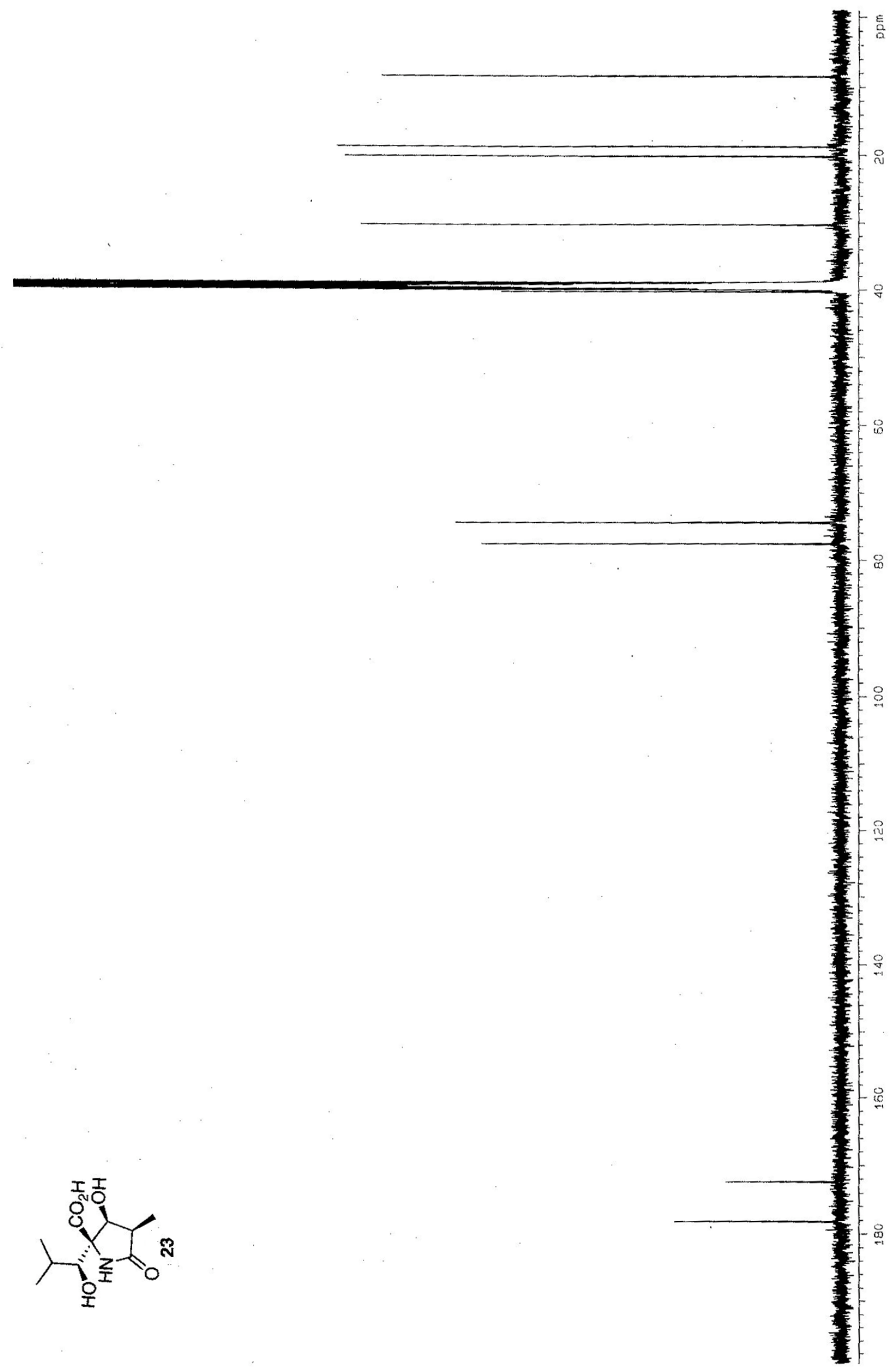

S25 


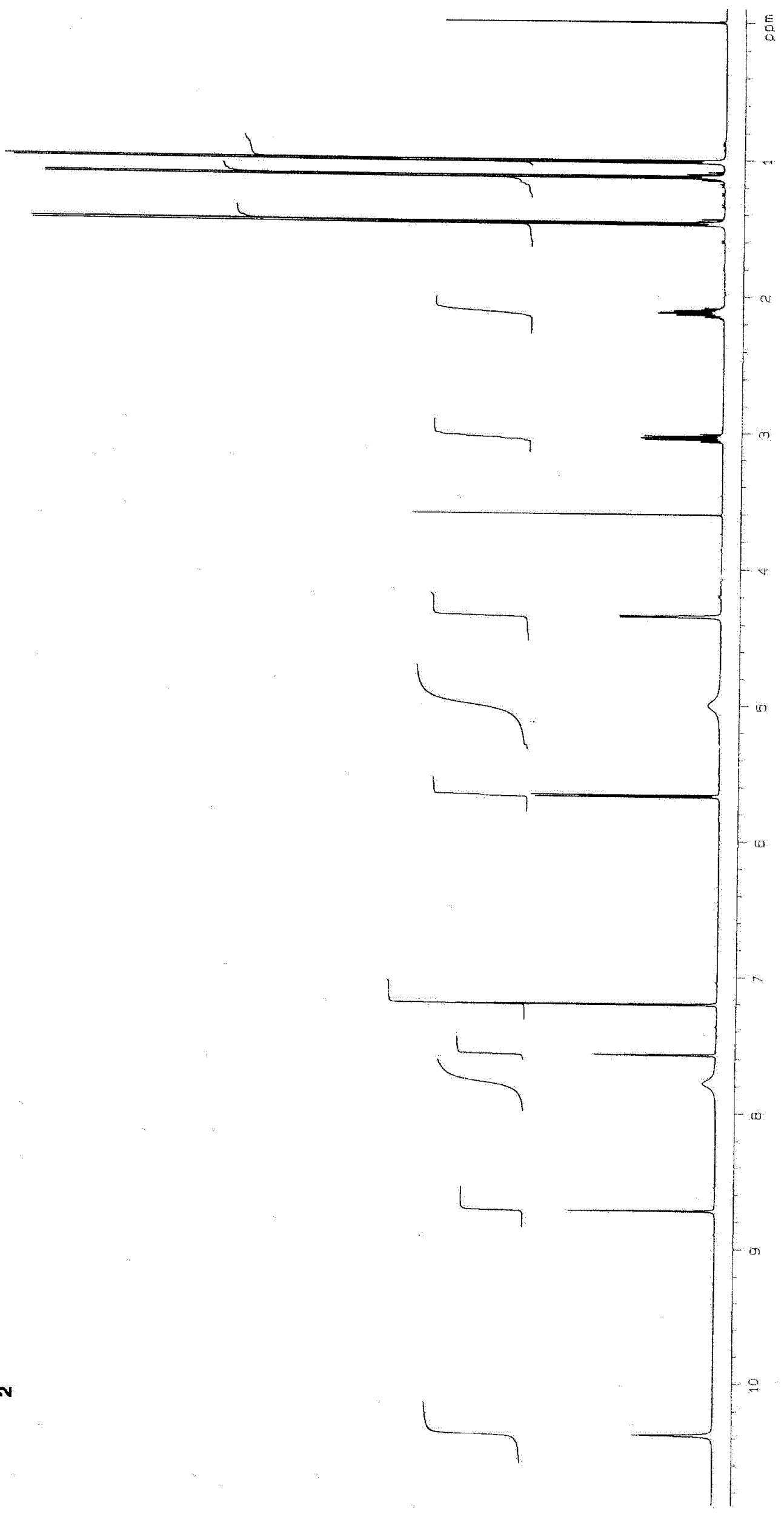




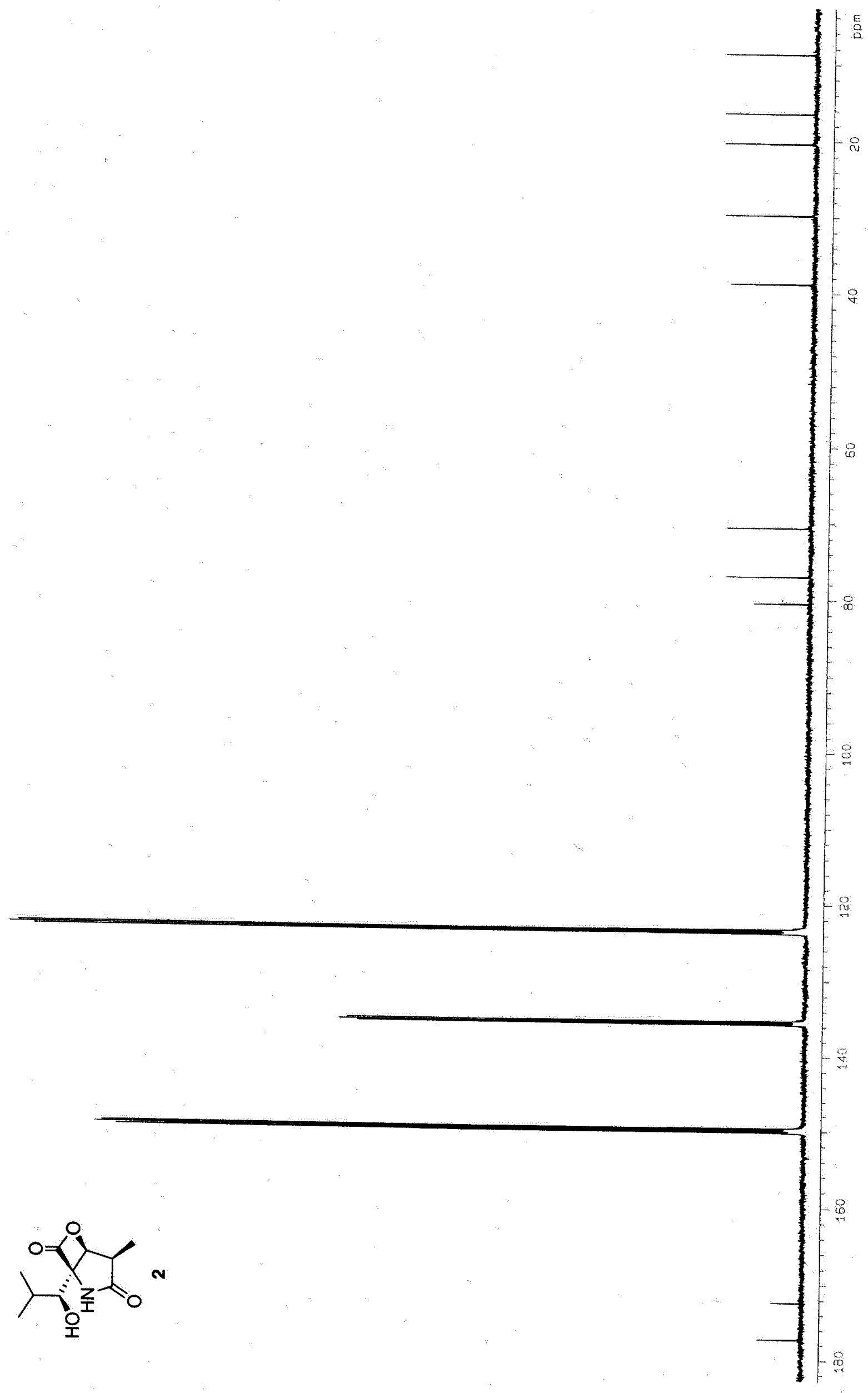




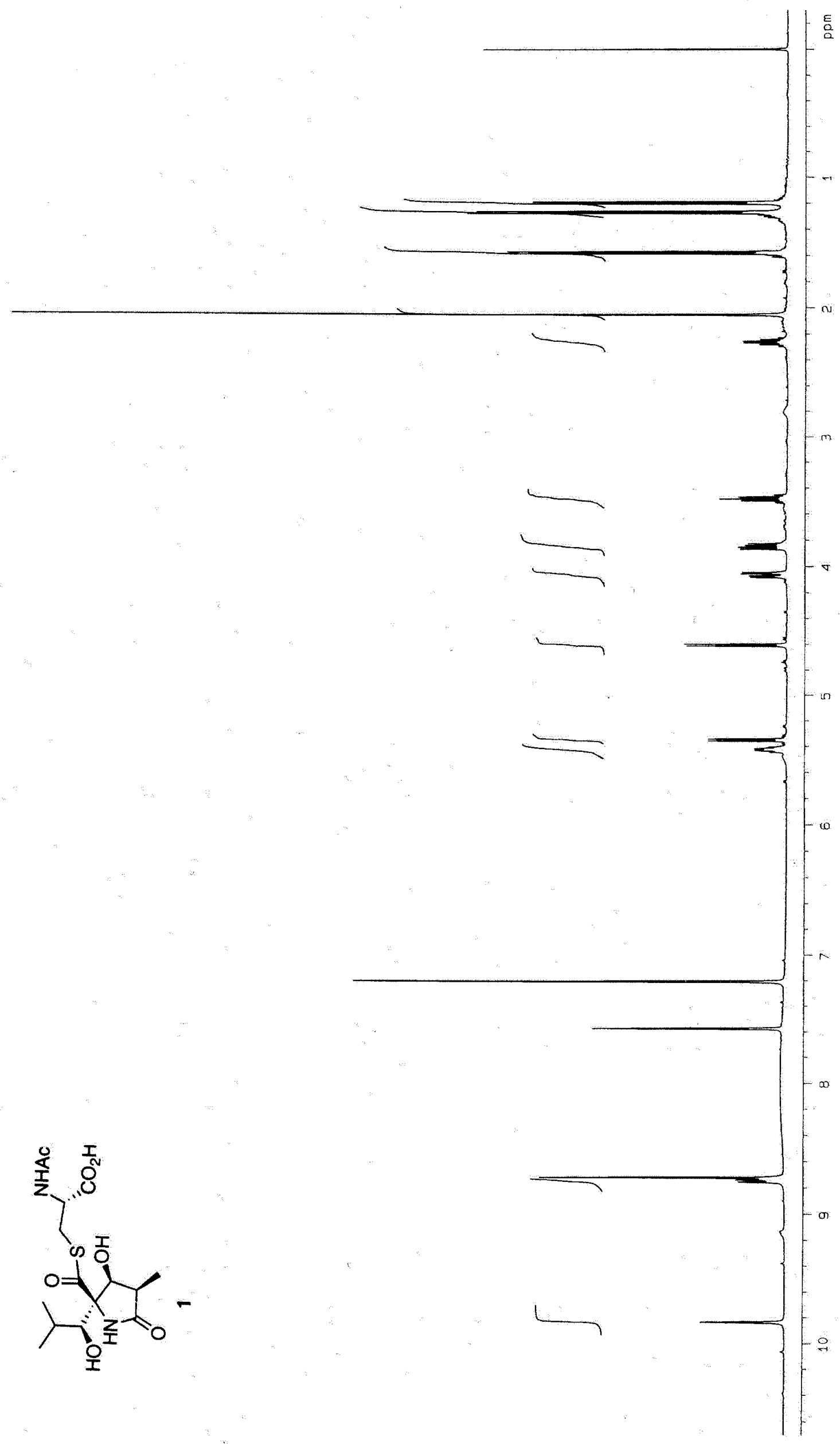




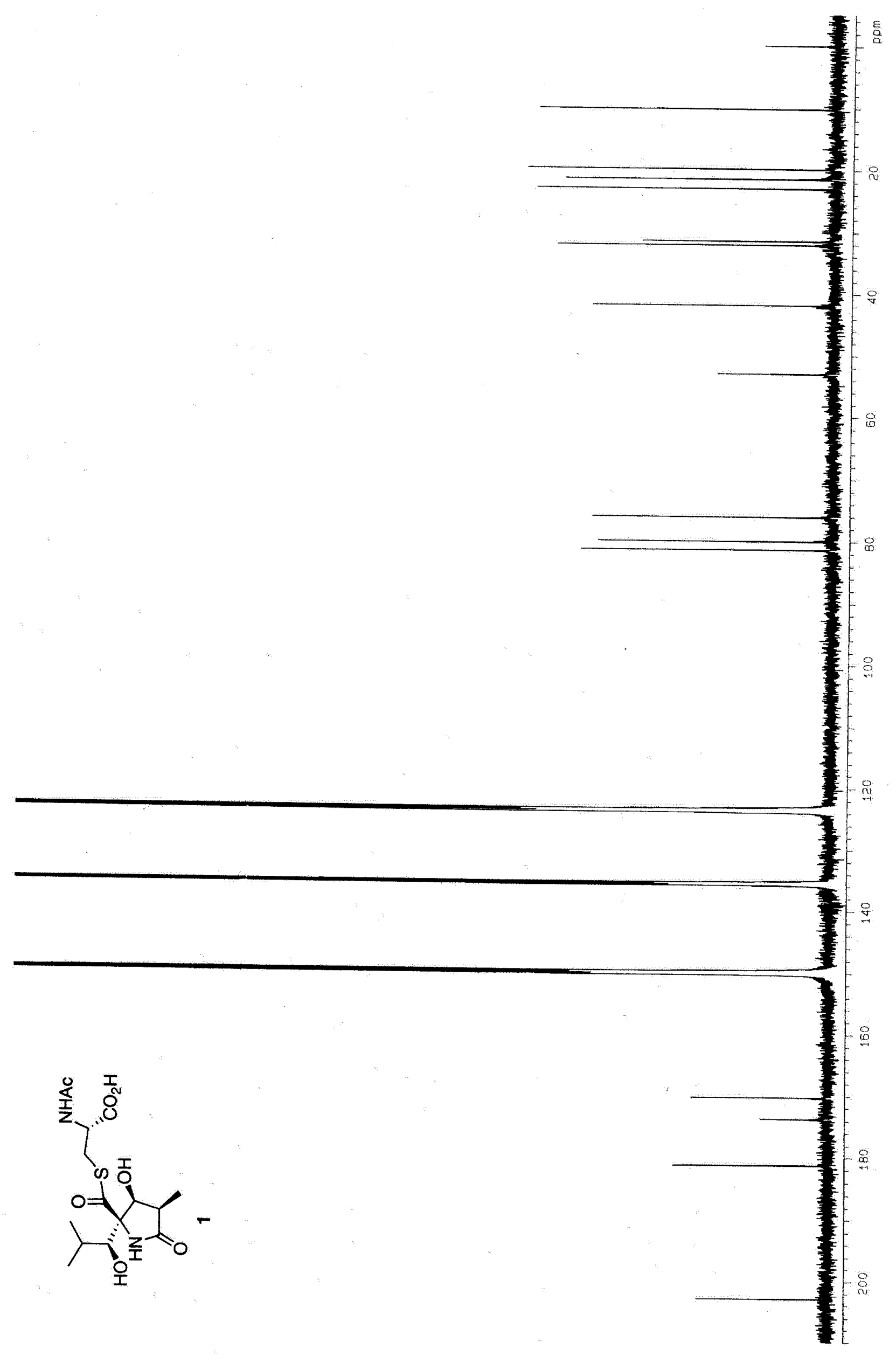

S29 